The New Nuns 



\section{The New Nuns}

RACIAL JUSTICE AND RELIGIOUS REFORM IN THE 1960s

AMY L. KOEHLINGER

HARVARD UNIVERSITY PRESS

Cambridge, Massachusetts, and London, England 2007 
Copyright (C) 2007 by the President and Fellows of Harvard College All rights reserved

Printed in the United States of America

ISBN-13: 978-0-674-02473-1

ISBN-10: 0-674-02473-7

Cataloging-in-Publication Data is available from the Library of Congress 
For my mother 
